\title{
EFFECT OF PREOPERATIVE RESPIRATORY REHABILITATION IN PATIENTS UNDERGOING CARDIAC SURGERY
}

\author{
Sonja Nejkov ${ }^{1}$, Vesna Bokan-Mirković ${ }^{1,2}$, Nataša Đukić-Macut ${ }^{3}$ and Marina Vuković, ${ }^{1,2}$ \\ ${ }^{1}$ Clinical Center of Montenegro, Department of Physical Medicine and Rehabilitation, Podgorica, Montenegro; \\ ${ }^{2}$ Faculty of Medicine, University of Montenegro, Podgorica, Montenegro; \\ ${ }^{3}$ Faculty of Medicine, University of Prishtina, Kosovska Mitrovica, Serbia
}

\begin{abstract}
SUMMARY - The aim of the study was to evaluate the effects of preoperative respiratory rehabilitation on functional capacity, length of stay in intensive care unit (ICU), duration of mechanical ventilation $(\mathrm{MV})$ and total hospitalization, as well as to estimate arterial blood gas $(\mathrm{ABG})$ values in patients undergoing cardiac surgery. Nineteen patients were included in the randomized observational study, divided into two groups: group A (intervention) and B (control). Preoperative and postoperative rehabilitation was performed in group A, and only postoperative rehabilitation in group $\mathrm{B}$. Rehabilitation was carried out according to a predefined protocol. We used ABG to evaluate respiratory function, two-minute walk test (2MWT) and sit-to-stand test to assess functional capacity. The following data were obtained from medical documentation: duration of MV, length of stay at ICU, occurrence of postoperative pulmonary complications, and length of total hospitalization in both groups. Significant between-group difference was found for the length of total hospitalization and duration of $M V$ ( $p<0.05$ both). Analysis of the mean values of $2 \mathrm{MWT}$ on the last day of hospitalization $(\mathrm{p}=0.005)$, sit-to-stand test before surgery $(\mathrm{p}=0.022)$ and on the last day of hospitalization $(\mathrm{p}=0.008)$ showed statistically significant differences. The length of hospital stay significantly correlated with preoperative rehabilitation in group A $(r=0.885 ; \mathrm{p}<0.0001)$. There was no difference in $\mathrm{ABG}$ parameters between the groups. The study showed that preoperative respiratory rehabilitation had an effect on reducing duration of MV and length of total hospitalization, and improved functional capacity.
\end{abstract}

Key words: Respiratory rehabilitation; Aorto-coronary bypass; Mechanical ventilation; Arterial blood gas analysis

\section{Introduction}

Cardiovascular diseases (CVD) were the most common underlying cause of death in the world and 17.9 million people died from CVD in 2016, accounting for $31 \%$ of all global deaths ${ }^{1}$. Coronary artery bypass graft $(\mathrm{CABG})$ surgery is a safe procedure for treatment of CVD with low rates of morbidity and

Correspondence to: Sonja Nejkor, MD, Clinical Center of Montenegro, Department of Physical Medicine and Rehabilitation, Ljubljanska bb, 81000 Podgorica, Montenegro

E-mail: sonjanejkov@gmail.com

Received February 12, 2019, accepted March 5, 2019 mortality in general ${ }^{2}$, and is still an excellent option for treatment of obstructive coronary artery disease ${ }^{3}$, in patients with diabetes ${ }^{4}$, elderly patients ${ }^{5}$, and patients with low left ventricular ejection fraction (LVEF) ${ }^{6}$. Although CABG surgery is successful, patients undergoing cardiac surgery are at a risk of postoperative pulmonary complications (PPC), which lead to increased postoperative morbidity and mortality ${ }^{7}$. The incidence of PPC varies from $20 \%$ to $95 \%$ depending on the type of surgery, and the most common complications are atelectasis (27\%-95\%) and pleural effusion (16.6\%$88 \%)^{8}$. PPC after cardiac surgery leads to prolonged hospitalization, large hospitalization costs, loss of 
working days, and even death. The most commonly recorded preoperative risk factors for PPC are age over 70 years, diabetes mellitus, body mass index (BMI) $>28$, preoperative arrhythmias or unstable angina pectoris, chronic obstructive pulmonary disease, smoking, and hepatic insufficiency.

In patients scheduled for cardiac surgery, cardiac rehabilitation (CR) significantly contributes to better prognosis, where the goal in the preoperative period is to prevent and minimize pulmonary complications, whereas in the postoperative period the goal is continuation of pulmonary expansion, rapid verticalization, and reduction in hospitalization length. The main goal of $\mathrm{CR}$ is to increase physical and psychosocial recovery after cardiac surgery and reduce the risk of future cardiac events by improving lifestyle ${ }^{9}$.In order to reduce the risk of PPC, it is best to start with physical therapy in the preoperative period. A few studies demonstrated that preoperative physical therapy (respiratory rehabilitation) had advantages over postoperative care alone in cardiac surgery patients ${ }^{7,8}$. There is a lack of evidence in the literature to standardize the measurement of postoperative complications and an objective measure of functional capacity in cardiac surgery patients. Walk tests are measures that could potentially be administered as part of the assessment to determine functional performance. Walk tests are widely used as a means of quantifying functional exercise capacity. The duration of the tests varies, but six-minute duration has been recommended by the American Thoracic Society ${ }^{10}$. Shorter walk tests, two-minute walk test (2MWT) in particular, are being used increasingly. In cardiac rehabilitation, 2MWT is a valid and reliable measure of functional $\mathrm{ca}^{-}$ pacity, and it is commonly used. This is an inexpensive and safe test of cardiovascular endurance in cardiac surgery population ${ }^{11}$.

The aim of the study was to evaluate the effects of preoperative respiratory rehabilitation on functional capacity, length of stay at the intensive care unit (ICU), duration of mechanical ventilation (MV), length of total hospitalization, and values of arterial blood gas $(\mathrm{ABG})$ parameters in patients undergoing cardiac surgery.

\section{Patients and Methods}

A simple randomized observational study was carried out over a six-month period at the Department of
Cardiac Surgery, Clinical Center of Montenegro. The study was approved by the Ethics Committee of the Clinical Center of Montenegro.

\section{Patients}

The study included 19 patients using percutaneous coronary intervention and diagnosed with three-vessel coronary disease (left anterior descending artery, circumflex artery or right coronary), severe luminal stenosis $>75 \%$, aortic valve stenosis and mitral valve stenosis.

\section{Exclusion criteria}

Patients with chronic respiratory disease, recent acute myocardial infarction (within 2 months), unstable cardiac disorders, patients scheduled for transcatheter aortic valve implantation, cognitive disorders, neurological disorders, musculoskeletal disorders, chronic renal insufficiency, emergency surgery, patients with LVEF $<40$ were excluded from the study. Prior to starting rehabilitation, cardiologic evaluation was performed in all patients. Patients received thorough explanation of the study protocol, were asked to participate in the study and provided verbal approval for it.

\section{Randomization}

There were 27 patients hospitalized at the Department of Cardiac Surgery, Clinical Center of Montenegro, scheduled for cardiac surgery (CABG surgery, aortic valve surgery, mitral valve surgery, or combined). After applying the inclusion and exclusion criteria, 19 patients were included in the study. Patients were randomized into two groups as follows: group A (intervention) received both preoperative and postoperative rehabilitation, whereas group B (control) received only postoperative rehabilitation.

Demographic data and preoperative risk factors were obtained by interview (age, sex, body weight, body height, BMI, current diagnoses, smoking history, myocardial infarction history, and comorbidities).

\section{Rehabilitation therapy}

Preoperative CR included the following: 1) diaphragmatic breathing and relaxation of the chest (10 deep breathing attempts, deep nasal inhaling and exhaling through the mouth); 2) postural education (training on protective positions and cough move- 
ments and initiation of the whole trunk and extremities); and 3) patient education about self-care and modification of risk factors. In group A, preoperative $\mathrm{CR}$ was performed twice a day.

Postoperative CR included the following: 1) diaphragmatic breathing (techniques to cleanse the lungs including mobilization, manual techniques, use of the active cycle of breathing); 2) postural education (on the position of the whole trunk, shoulder and pelvis in the lying and sitting positions in bed); 3) active exercises in bed for mobilizing distal and middle segments of lower extremities (prevention of deep vein thrombosis and pulmonary embolism; 4) transferring from supination to sitting over the edge of the bed; 5) diaphragmatic breathing in sitting position in bed; 6) transferring from sitting to standing position next to the edge of the bed (verticalization of the patient with the bed), stepping near the edge of the bed with assistance of a physiotherapist; and 7) walking with the assistance of a physiotherapist to stand-alone walk of 50-200 m. Postoperative CR was initiated two hours after patient extubation in ICU and was implemented until the end of hospitalization. Postoperative $\mathrm{CR}$ was performed three times a day in both groups $\mathrm{A}$ and $\mathrm{B}$.

Termination criteria for rehabilitation therapy were as follows: arterial blood pressure $<65 \mathrm{~mm} \mathrm{Hg}$ or $>160$ $\mathrm{mm} \mathrm{Hg}$, heart rate $<50$ beats $/ \mathrm{min}$ or $>130$ beats $/ \mathrm{min}$, respiratory rate $<12$ breaths $/ \mathrm{min}$ or $>40$ breaths $/ \mathrm{min}$, pulse oximetry $<80 \%$, heart rhythm disorders, acute bleeding, acute myocardial infarction, dehiscence of the wound, disturbance of consciousness, and acute psychiatric conditions.

We used the following ABG parameters to evaluate respiratory function in both groups: partial pressure of carbon dioxide $\left(\mathrm{PCO}_{2}\right)$, partial oxygen pressure $\left(\mathrm{PO}_{2}\right)$, bicarbonate $\left(\mathrm{HCO}_{3}\right)$, and oxygen saturation $\left(\mathrm{O}_{2} \mathrm{sat}\right)$. The parameters were measured two hours after extubation in ICU and then just before leaving the ICU.

To evaluate functional capacity, we used 2MWT and sit-to-stand test. Patients performed 2MWT and sit-to-stand test on the first day of hospitalization, before surgery, and on the last day of hospitalization in both groups.

Data obtained from medical documentation were duration of $\mathrm{MV}$, length of stay at ICU, occurrence of PPC, and length of total hospitalization in both groups.

\section{Clinical assessment}

We used the following ABG parameters to evaluate respiratory function in both groups: $\mathrm{PCO}_{2}, \mathrm{PO}_{2}$, $\mathrm{HCO}_{3}$ and $\mathrm{O}_{2}$ sat. The parameters were measured two hours after extubation in ICU and then just before leaving the ICU.

To evaluate functional capacity, we used 2MWT and sit-to-stand test. Patients performed 2MWT and sit-to-stand test on the first day of hospitalization, before surgery, and on the last day of hospitalization in both groups.

Data obtained from medical documentation included duration of MV, length of stay in ICU, occurrence of PPC, and length of total hospitalization in both groups.

\section{Statistical analysis}

Descriptive statistical analysis revealed the following statistical parameters: arithmetic mean, standard deviation, minimum $(\mathrm{min})$ and maximum value $(\max )$, absolute frequency $(\mathrm{N})$ and structure index (\%).

Analytical statistical methodology was employed to assess statistical significance of differences in the mean values of particular parameters between the two study groups. We used parametric tests and nonparametric tests in case of the coefficient of variation $>30 \%$. Comparison of the frequency of reporting individual modalities of attributive features between the groups was performed by Pearson $\chi^{2}$-test/Fisher exact test. We used Student's t-test or Mann-Whitney U-test for comparison of the mean values between the two groups. Pearson correlation analysis was used to measure the association of particular parameters.

Statistical analysis was performed using the Excel program, Microsoft Office software, and PASW version 18.0. As the statistical significance threshold, the estimation error was less than $5 \%(p<0.05)$.

\section{Results}

Nineteen patients were randomly assigned into two groups, A ( $n=11)$ and B ( $n=8)$. All patients completed the scheduled rehabilitation. There were no significant differences in demographic characteristics between the groups (sex, age, BMI, or smoking status) (Table 1). 
Table 1. Demographic characteristics of two patient groups

\begin{tabular}{|c|c|c|c|c|c|c|}
\hline & \multicolumn{2}{|c|}{ Group } & \multirow{2}{*}{ Total } & \\
\hline & & & Control & Intervention & & \\
\hline \multirow[t]{6}{*}{ Sex } & \multirow[t]{3}{*}{ Male } & \multirow{3}{*}{$\begin{array}{l}\mathrm{n} \\
\% \text { group } \\
\% \text { of total }\end{array}$} & \multirow{3}{*}{\begin{tabular}{|l}
5 \\
$62.5 \%$ \\
$26.3 \%$ \\
\end{tabular}} & \multirow{3}{*}{\begin{tabular}{|l|}
8 \\
$72.7 \%$ \\
$42.1 \%$ \\
\end{tabular}} & \multirow{3}{*}{$\begin{array}{l}13 \\
68.4 \% \\
68.4 \% \\
\end{array}$} & Fisher exact test \\
\hline & & & & & & \multirow{5}{*}{$\mathrm{p}=0.506$} \\
\hline & & & & & & \\
\hline & Female & $\mathrm{n}$ & 3 & 3 & 6 & \\
\hline & & $\%$ group & $37.5 \%$ & $27.3 \%$ & $31.6 \%$ & \\
\hline & & $\%$ of total & $15.8 \%$ & $15.8 \%$ & $31.6 \%$ & \\
\hline \multirow{2}{*}{\multicolumn{2}{|c|}{ Age (yrs) }} & & $64.75 \pm 4.268$ & $61.18 \pm 9.673$ & $62.68 \pm 7.89$ & $\mathrm{t}=0.971$ \\
\hline & & & $55-68$ & $44-73$ & $44-73$ & $\mathrm{p}=0.345$ \\
\hline \multirow{2}{*}{\multicolumn{2}{|c|}{ Body mass index $\left(\mathrm{kg} / \mathrm{m}^{2}\right)$}} & & $26.137 \pm 3.01$ & $27.082 \pm 3.60$ & $26.68 \pm 3.31$ & $t=0.604$ \\
\hline & & & $22.1-30.1$ & $21.8-32.4$ & $21.8-32.4$ & $\mathrm{p}=0.554$ \\
\hline \multirow{9}{*}{$\begin{array}{l}\text { Smoking } \\
\text { history }\end{array}$} & Non-smokers & $\mathrm{n}$ & 4 & 3 & 7 & \multirow{12}{*}{$\begin{array}{l}\chi^{2}=1.028 \\
p=0.598\end{array}$} \\
\hline & & $\%$ group & $50.0 \%$ & $27.3 \%$ & $36.8 \%$ & \\
\hline & & $\%$ of total & $21.1 \%$ & $15.8 \%$ & $36.8 \%$ & \\
\hline & Ex-smokers & & 2 & 4 & 6 & \\
\hline & & & $25.0 \%$ & $36.4 \%$ & $31.6 \%$ & \\
\hline & & & $10.5 \%$ & $21.1 \%$ & $31.6 \%$ & \\
\hline & Smokers & $\mathrm{n}$ & 2 & 4 & 6 & \\
\hline & & $\%$ group & $25.0 \%$ & $36.4 \%$ & $31.6 \%$ & \\
\hline & & $\%$ of total & $10.5 \%$ & $21.1 \%$ & $31.6 \%$ & \\
\hline \multirow{3}{*}{\multicolumn{2}{|c|}{ Total }} & $\mathrm{N}$ & 8 & 11 & 19 & \\
\hline & & $\%$ group & $100.0 \%$ & $100.0 \%$ & $100.0 \%$ & \\
\hline & & $\%$ of total & $42.1 \%$ & $57.9 \%$ & $100.0 \%$ & \\
\hline
\end{tabular}

The mean duration of preoperative rehabilitation was $6.73 \pm 2.76$ days. Comparing the mean values of the length of stay at ICU (A: $2.73 \pm 0.95$ and B: $3.50 \pm 1.069)$, there were no significant differences between the groups. Comparison of the mean length of total hospitalization in group A $(11.27 \pm 1.794)$ and group B $(16.88 \pm 3.357)$ revealed significant betweengroup differences $(\mathrm{p}=0.002)$. The mean duration of MV was $24.63 \pm 10.460$ and $15.64 \pm 7.778$ in group A and $\mathrm{B}$, respectively, yielding significant differences between the two groups $(p=0.038)$ (Table 2). Evaluation of the mean values of ABG parameters showed no significant difference between the two groups (Table 3). Considering functional capacity parameters, only the mean values of $2 \mathrm{MWT}$ before surgery showed no statistically significant differences between the two groups. Analysis of the mean values of $2 \mathrm{MWT}$ on the last day of hospitalization ( $\mathrm{p}=0.005)$, and of the sit-tostand test before surgery $(\mathrm{p}=0.022)$ and on the last day of hospitalization in both groups $(\mathrm{p}=0.008)$ showed significant differences between the two groups (Table 4). Analysis of the occurrence of complications (complications reported with yes/no in both groups) showed no significant differences between the groups (Fisher exact test, $\mathrm{p}=0.067$ ) (Table 5). In group $\mathrm{A}$, significant correlation was recorded between the length of hospitalization and duration of preoperative rehabilitation $(r=0.885 ; p<0.0001)$ (Fig. 1).

\section{Discussion}

Nowadays, the profile of patients undergoing $\mathrm{CABG}$ is changing to a higher-risk profile, i.e. elderly patients with comorbid medical problems. Our study was so designed to examine whether preoperative rehabilitation in patients undergoing cardiac surgery had an effect of reducing the length of stay at ICU, duration of MV, occurrence of PPC, and length of total 
Table 2. Length of ICU stay, total hospitalization and mechanical ventilation in two patient groups

\begin{tabular}{|l|l|l|l|l|l|}
\hline & & $\mathrm{n}$ & Mean & SD & $\mathrm{t}$-test \\
\hline Length of hospital stay (days) & Control & 8 & 16.88 & 3.357 & $\mathrm{t}=4.717$ \\
& Intervention & 11 & 11.27 & 1.794 & ${ }^{\mathrm{p}=0.002}$ \\
\hline Length of ICU stay (days) & Control & 8 & 3.50 & 1.069 & $\mathrm{t}=1.705$ \\
& Intervention & 11 & 2.73 & 0.905 & $\mathrm{p}=0.106$ \\
\hline $\mathrm{MV}(\mathrm{h})$ & Control & 8 & 24.63 & 10.460 & $\mathrm{Z}=2.071$ \\
& Intervention & 11 & 15.64 & 7.788 & ${ }^{\mathrm{p}}=0.038$ \\
\hline
\end{tabular}

$\mathrm{ICU}=$ intensive care unit; $\mathrm{MV}=$ mechanical ventilation; Intervention (group A); Control (group B); SD = standard deviation; ${ }^{*} \mathrm{p}<0.05$

Table 3. Arterial blood gas parameters $(A B G)$

\begin{tabular}{|l|l|l|l|l|l|}
\hline & Group & $\mathrm{n}$ & Mean & $\mathrm{SD}$ & $\mathrm{t}$-test \\
\hline PCO2_I & Control & 8 & 46.50 & 6.568 & $\mathrm{t}=1.185$ \\
& Intervention & 11 & 41.78 & 9.726 & $\mathrm{p}=0.252$ \\
\hline PO2_I & Control & 8 & 117.63 & 33.979 & $\mathrm{t}=0.449$ \\
& Intervention & 11 & 124.45 & 31.851 & $\mathrm{p}=0.659$ \\
\hline HCO3_I & Control & 8 & 28.138 & 5.1887 & $\mathrm{t}=1.101$ \\
& Intervention & 11 & 25.982 & 3.3695 & $\mathrm{p}=0.286$ \\
\hline $\mathrm{SO}_{2-I}$ & Control & 8 & 91.775 & 15.1219 & $\mathrm{t}=1.701$ \\
& Intervention & 11 & 99.464 & 0.9080 & $\mathrm{p}=0.107$ \\
\hline PCO2_Z & Control & 8 & 41.75 & 5.285 & $\mathrm{t}=0.099$ \\
& Intervention & 11 & 42.09 & 8.642 & $\mathrm{p}=0.923$ \\
\hline PO2_Z & Control & 8 & 121.45 & 19.430 & $\mathrm{t}=1.612$ \\
& Intervention & 11 & 137.27 & 22.222 & $\mathrm{p}=0.125$ \\
\hline HCO3_Z & Control & 8 & 28.01 & 3.060 & $\mathrm{t}=0.371$ \\
& Intervention & 11 & 28.59 & 3.540 & $\mathrm{p}=0.715$ \\
\hline SO 2 Z & Control & 8 & 97.837 & 1.5982 & $\mathrm{t}=1.373$ \\
& Intervention & 11 & 92.691 & 10.4308 & $\mathrm{p}=0.188$ \\
\hline
\end{tabular}

$\mathrm{SD}$ = standard deviation; PCO2_I = partial pressure of carbon dioxide two hours after patient extubation; PO2_I = partial oxygen pressure two hours after patient extubation; HCO3_I = bicarbonate two hours after patient extubation; SO2_I = oxygen saturation two hours after patient extubation; $P C O 2 \_Z=$ partial pressure of carbon dioxide immediately before patient transfer from the intensive care unit (ICU); PO2_Z = partial oxygen pressure just before patient transfer from the ICU; $\mathrm{HCO} 3 \_Z=$ bicarbonate just before patient transfer from the ICU; SO2_Z = oxygen saturation just before patient transfer from the ICU

hospitalization. It was also examined whether there was a difference in the values of ABG parameters between the groups. We also examined functional capacity using the 2MWT and sit-to-stand test.

A limited number of studies evaluated the effect of preoperative respiratory rehabilitation in patients undergoing cardiac surgery ${ }^{12,13}$. In our study, preoperative respiratory rehabilitation significantly influenced the length of total hospitalization, which is one of the benefits of preoperative respiratory rehabilitation, similar to the results of several studies ${ }^{8,14}$. Arthur et al. demonstrated that preoperative physical training reduced the length of hospitalization ${ }^{14}$. We did not find an effect of preoperative rehabilitation on ICU length of stay, although Snowdon et al. ${ }^{15}$ have reported such a connection. The mean ICU length of stay was $2.73 \pm 0.90$ days in group $A$, which did not differ significantly from group B ( $3.50 \pm 1.07$ days). Mansueto $e t$ 
Table 4. Functional capacity parameters

\begin{tabular}{|l|l|l|l|l|l|}
\hline & Groups & $\mathrm{n}$ & Mean & $\mathrm{SD}$ & $\mathrm{t}$-test \\
\hline 2MWT-before & Control & 8 & 110.75 & 14.140 & $\mathrm{t}=0.778$ \\
(meters) & Intervention & 11 & 116.73 & 18.023 & $\mathrm{p}=0.447$ \\
\hline Sit-stand- before & Control & 8 & 7.63 & 3.204 & $\mathrm{Z}=2.297$ \\
& Intervention & 11 & 9.36 & 1.433 & $\mathrm{p}=0.022$ \\
\hline 2MWT-last-day & Control & 8 & 96.25 & 8.102 & $\mathrm{t}=3.257$ \\
(meters) & Intervention & 11 & 110.27 & 10.001 & $\mathrm{p}=0.005$ \\
\hline sit-stand-last day & Control & 8 & 4.50 & 0.926 & $\mathrm{t}=2.996$ \\
& Intervention & 11 & 6.91 & 2.119 & $\mathrm{p}=0.008$ \\
\hline
\end{tabular}

$\mathrm{SD}=$ standard deviation; $2 \mathrm{MWT}$-before = two-minute walk test before cardiac rehabilitation; sit-stand-before = sitto-stand test before cardiac rehabilitation; 2MWT-last-day = two-minute walk test after cardiac rehabilitation; sitstand-last day $=$ sit-to stand test after cardiac rehabilitation

Table 5. Occurrence of complications

\begin{tabular}{|c|c|c|c|c|c|}
\hline & & & & troup & \\
\hline & & & Control & Intervention & Total \\
\hline Complications & No & $\begin{array}{l}\mathrm{n} \\
\% \text { within group } \\
\% \text { of total } \\
\end{array}$ & \begin{tabular}{|l|}
3 \\
$37.50 \%$ \\
$15.79 \%$ \\
\end{tabular} & \begin{tabular}{|l|}
9 \\
$81.82 \%$ \\
$47.37 \%$ \\
\end{tabular} & \begin{tabular}{|l|}
12 \\
$63.16 \%$ \\
$63.13 \%$ \\
\end{tabular} \\
\hline & Yes & $\begin{array}{l}\mathrm{n} \\
\% \text { within group } \\
\% \text { of total }\end{array}$ & \begin{tabular}{|l|}
5 \\
$62.50 \%$ \\
$26.32 \%$ \\
\end{tabular} & \begin{tabular}{|l|}
2 \\
$18.18 \%$ \\
$10.53 \%$ \\
\end{tabular} & $\begin{array}{l}7 \\
36.84 \% \\
36.84 \% \\
\end{array}$ \\
\hline Total & & $\mathrm{N}$ & 8 & 11 & 19 \\
\hline & & $\%$ within group & $100.0 \%$ & $100.0 \%$ & $100.0 \%$ \\
\hline & & $\%$ of total & $42.11 \%$ & $57.89 \%$ & $100.0 \%$ \\
\hline
\end{tabular}

$a l .^{16}$ also report that preoperative inspiratory muscle training resulted in reduction of the length of postoperative hospital stay.

The results of our study revealed preoperative rehabilitation to have reduced the duration of $\mathrm{MV}$, as also indicated in the study by Hulzebos et al. ${ }^{13}$. Zanini et $a l .^{17}$ report that preoperative respiratory rehabilitation was associated with the duration of MV in patients undergoing cardiac surgery. Also, rehabilitation minimized the possibility of MV complication and accelerated the speed of patient recovery. Hulzebos et al. ${ }^{7}$ showed that preoperative physical therapy could reduce the length of MV, incidence of PPC (atelectasis and pneumonia), and length of total hospitalization in patients undergoing cardiovascular surgery. Moreover, in patients in whom preoperative respiratory rehabilitation was performed, the incidence of PPC was decreased by $50 \%$ in comparison to patients who had conventional $\mathrm{care}^{13}$. Preoperative respiratory rehabilitation was associated with reduction in the occurrence of postoperative atelectasis and pneumonia, compared to patients who received conventional care or non-exercise intervention ${ }^{18}$.

In our study, the results on the incidence of complications (complications reported by yes/no in both groups) did not differ significantly between the groups, but there was difference in the rate of complications between group A (2 complications) and group B (5 complications).

Evaluation of the ABG parameters did not show differences between the two groups.

Moradian et al. ${ }^{19}$ suggest that early mobilization in the postoperative period in patients after CABG increased partial oxygen pressure in arterial blood. There are a small number of studies that examined the effects of preoperative respiratory rehabilitation on respirato- 


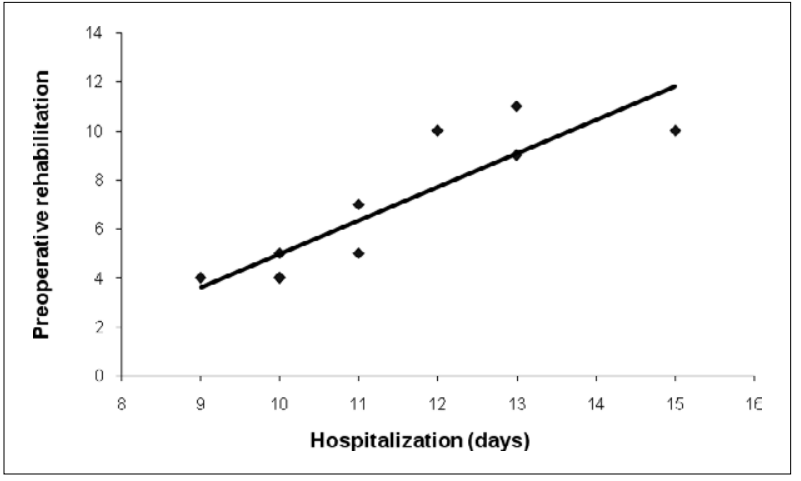

Fig. 1. Correlation between length of hospital stay and preoperative rehabilitation in the intervention group.

ry function based on ABG parameters, so additional studies on the topic are considered necessary.

The results of our study demonstrated significant differences between the groups in the mean values of 2MWT on the last day of hospitalization, sit-to-stand test before and after surgery (last day of hospitalization) in both groups. We chose to investigate $2 \mathrm{MWT}$ because it is a practical and feasible test to apply before and after cardiac surgery.

Our study showed strong correlation between the length of hospitalization and preoperative rehabilitation in group A, suggesting that the implementation of preoperative rehabilitation is necessary in patients undergoing cardiac surgery.

A limitation of the study was a small sample because cardiac surgery was postponed after repeated angiography in a great number of patients.

\section{Conclusion}

The study showed that preoperative respiratory rehabilitation reduced the duration of MV and total length of hospitalization in cardiac surgery patients. The results also showed that preoperative respiratory rehabilitation could have favorable effects on patient functional capacity. Study results suggest the implementation of preoperative rehabilitation to be necessary in patients undergoing cardiac surgery.

\section{References}

1. Benjamin EJ, Blaha MJ, Chiuve SE, et al. Heart Disease and Stroke Statistics - 2017 Update: a report from the American
Heart Association. Circulation. 2017 March 07;135(10):e146e603. doi: 10.1161/CIR.0000000000000485

2. Aikawa P, Cintra AR, Leite CA, Marques RH, Silva CT, Afonso MS, et al. Impact of coronary artery bypass grafting in elderly patients. Rev Bras Cir Cardiovasc. 2013;28(1):22-8. http://dx.doi.org/10.5935/1678-9741.20130005

3. Dallan LAO, Jatene FB. Myocardial revascularization in the XXI century. Braz J Cardiovasc Surg. 2013;28(1):137-44. doi: 10.5935/1678-9741.20130017

4. Stevens LM, Carrier M, Perrault LP, Hébert Y, Cartier R, Bouchard D, Fortier A, Pellerin M. Influence of diabetes and bilateral internal thoracic artery grafts on long-term outcome for multivessel coronary artery bypass grafting. Eur J Cardiothorac Surg. 2005 Feb;27(2):281-8. doi: 10.1016/j.ejcts.2004. 10.048

5. Kieser TM, Lewin AM, Graham MM, Martin BJ, Galbraith PD, Rabi DM, et al. Outcomes associated with bilateral internal thoracic artery grafting: the importance of age. Ann Thorac Surg. 2011;92(4):1269-75. doi: 10.1016/j.athoracsur.2011.05. 083, 2011 Oct

6. Galbut DL, Kurlansky PA, Traad EA, Dorman MJ, Zucker M, Ebra G. Bilateral internal thoracic artery grafting improves long-term survival in patients with reduced ejection fraction: a propensity-matched study with 30-year follow-up. J Thorac Cardiovasc Surg. 2012;143(4):844-53. doi: 10.1016/j.jtcvs. 2011.12.026, 2012 Apr

7. Hulzebos EH, Smit Y, Helders PP, van Meeteren NL. Preoperative physical therapy for elective cardiac surgery patients. Cochrane Database Syst Rev. 2012;11:CD010118. doi: 10.1002/14651858, 2012 Nov

8. Shakouri SK, Salekzamani Y, Taghizadieh A, Sabbagh-Jadid $\mathrm{H}$, Soleymani J, Sahebi L, Sahebi R. Effect of respiratory rehabilitation before open cardiac surgery on respiratory function: a randomized clinical trial. J Cardiovasc Thorac Res. 2015;7(1): 13-7. doi: 10.15171/jcvtr.2015.03, $2015 \mathrm{Mar}$

9. Achttien RJ, Staal JB, van der Voort S, Kemps HM, Koers H, Jongert MW, Hendriks EJ; Practice Recommendations Development Group. Exercise-based cardiac rehabilitation in patients with coronary heart disease: a practice guideline. Neth Heart J. 2013 Oct;21(10):429-38. doi: 10.1007/s12471-0130467, 2013 Oct

10. ATS Committee on Proficiency Standards for Clinical Pulmonary Function Laboratories: ATS statement: guidelines for the six-minute walk test. Am J Respir Crit Care Med. 2002; 166:111-7. https://doi.org/10.1164/ajrccm.166.1.at1102

11. Bohannon RW. Normative reference values for the two-minute walk test derived by meta-analysis. J Phys Ther Sci. 2017 Dec;29(12):2224-7. doi: 10.1589/jpts.29.2224

12. Herdy AH, Marcchi PL, Vila A, Tavares C, Collaço J, Niebauer J, Ribeiro JP. Pre- and postoperative cardiopulmonary rehabilitation in hospitalized patients undergoing coronary artery bypass surgery: a randomized controlled trial. Am J Phys Med Rehabil. 2008 Sep;87(9):714-9. doi: 10.1097/PHM. 0b013e3181839152 
13. Hulzebos EH, Helders PJ, Favié NJ, De Bie RA, Brutel de la Riviere A, Van Meeteren NL. Preoperative intensive inspiratory muscle training to prevent postoperative pulmonary complications in high-risk patients undergoing CABG surgery. JAMA. 2006 Oct 18;296(15):1851-7. doi: 10.1001/jama.296. 15.1851

14. Arthur HM, Daniels C, McKelvie R, Hirsh J, Rush B. Effect of a preoperative intervention on preoperative and postoperative outcomes in low-risk patients awaiting elective coronary artery bypass graft surgery: a randomized, controlled trial. Ann Intern Med. 2000 Aug 15;133(4):253-62. doi: 10.7326/0003-4819133-4-200008150-00007

15. Snowdon D, Haines TP, Skinner EH. Preoperative intervention reduces postoperative pulmonary complications but not length of stay in cardiac surgical patients: a systematic review. J Physiother. 2014 Jun;60(2):66-77. doi: 10.1016/j.jphys.2014.04.002.

16. Gomes Neto M, Martinez BP, Reis HF, Carvalho VO. Preand postoperative inspiratory muscle training in patients undergoing cardiac surgery: systematic review and meta-analysis.
Clin Rehabil. 2017 Apr;31(4):454-64. doi: 10.1177/026921 5516648754

17. Zanini M, Nery RM, Buhler RP, de Lima JB, Stein R. Preoperative maximal expiratory pressure is associated with duration of invasive mechanical ventilation after cardiac surgery: an observational study. Heart Lung. 2016 May-Jun;45(3):244-8. doi: 10.1016/j.hrtlng.2016.01.003

18. Katsura M, Kuriyama A, Takeshima T, Fukuhara S, Furukawa TA. Preoperative inspiratory muscle training for postoperative pulmonary complications in adults undergoing cardiac and major abdominal surgery (Review). Cochrane Database Syst Rev. 2015 Oct 5;10:CD010356. doi: 10.1002/14651858. CD010356

19. Moradian ST, Najafloo M, Mahmoudi H, Ghiasi MS. Early mobilization reduces the atelectasis and pleural effusion in patients undergoing coronary artery bypass graft surgery: a randomized clinical trial. J Vasc Nurs. 2017 Sep;35(3):141-5. doi: 10.1016/j.jvn.2017.02.001

Sažetak

\title{
UTJECAJ PRIJEOPERACIJSKE RESPIRACIJSKE REHABILITACIJE KOD KARDIOKIRURŠKIH BOLESNIKA
}

\author{
S. Nejkov, V. Bokan-Mirković, N. Đukić-Macut i M. Vuković
}

Cilj rada je bio procijeniti učinak prijeoperacijske respiracijske rehabilitacije na funkcionalni kapacitet, dužinu boravka u jedinici intenzivnog liječenja (JIL), trajanje mehaničke ventilacije (MV) i ukupnu hospitalizaciju te procijeniti vrijednosti plinske analize arterijske krvi (ABG) kod bolesnika podvrgnutih kardiokirurškim operacijama. U radomiziranu opservacijsku studiju bilo je uključeno 19 bolesnika podijeljenih u dvije skupine: skupina A (ispitivana) i B (kontrolna). Prijeoperacijska i poslijeoperacijska rehabilitacija provedena je u skupini A, a samo poslijeoperacijska rehabilitacija u skupini B. Rehabilitacija je provođena prema unaprijed utvrđenom protokolu. Rabili smo parametre ABG za procjenu respiracijske funkcije, a za procjenu funkcionalnog kapaciteta 2-minutni test hoda (2MWT) i sit-to-stand test. Sljedeći podaci prikupljeni su iz medicinske dokumentacije: dužina MV, dužina boravka u JIL, pojava komplikacija i dužina ukupne hospitalizacije. Nađena je značajna razlika između skupina za dužinu ukupne hospitalizacije $(\mathrm{p}<0,05)$ i dužinu $\mathrm{MV}(\mathrm{p}<0,05)$. Analiza srednjih vrijednosti 2MWT posljednjeg dana hopitalizacije $(\mathrm{p}=0,005)$, sit-to-stand testa prije operacije $(\mathrm{p}=0,022)$ i posljednjeg dana hospitalizacije $(\mathrm{p}=0,008)$ između skupina pokazala je statistički značajnu razliku. Dužina hospitalizacije je značajno korelirala s prijeoperacijskom rehabilitacijom u skupini A $(r=0,885 ; p<0,0001)$. Nije bilo razlike u parametrima ABG između skupina. Studija je pokazala da je prijeoperacijska respiracijska rehabilitacija utjecala na smanjenje dužine MV, dužinu trajanja ukupne hospitalizacije te na poboljšanje funkcionalnog kapaciteta.

Ključne riječi: Respiracijska rehabilitacija; Aortokoronarna premosnica; Mehanička ventilacija; Plinska analiza arterijske krvi 